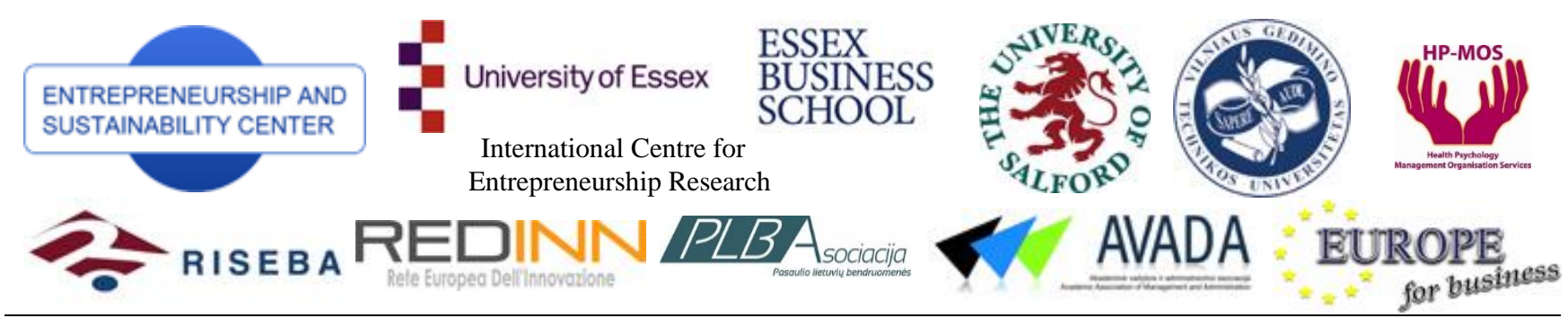

ENTREPRENEURSHIP AND SUSTAINABILITY ISSUES

ISSN 2345-0282 (online) http://jssidoi.org/jesi/

\title{
SOME ASPECTS OF CRIMINAL ENVIRONMENT IMPACT ON SUSTAINABLE ENTREPRENEURSHIP ACTIVITIES
}

\author{
Jānis Teivāns-Treinovskisis , Jeḷena Amosova² \\ ${ }^{1,2}$ Daugavpils University, Vienibas Str. 13, LV-5400 Daugavpils, Latvia

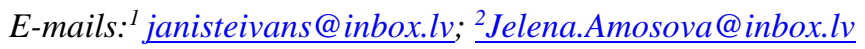

Received 20 March 2016; accepted 15 June 2016

\begin{abstract}
In the Republic of Latvia there are sufficient conditions for engaging representatives of different layers of society in doing business and entrepreneurship activities. At the same time, some businessmen lack legal behaviour skills on the market and underdeveloped legal culture and low legal awareness have often led and still lead to violation of Latvian legislation including the criminal one. This undoubtedly contributes to the increase in crime in business sphere. The aim of the given article is to examine several aspects of criminal environment impact on business activity. In the article two major problems will be dealt with - the shadow economy and corruption, which from the author's point of view exert direct influence on business activity and reveal the connections of some of its parts with criminal environment. The problems of the shadow economy and corruption are topical both within the Republic of Latvia and internationally. A number of international researches are being conducted to evaluate the scale of these phenomena and to devise effective methods to fight them, which once more proves the topicality and urgency of the analysed theme.
\end{abstract}

Keywords: criminal environment, corruption, shadow economy

Reference to this paper should be made as follows: Teivāns-Treinovskis, J.; Amosova, J. 2016. Some aspects of criminal environment impact on sustainable entrepreneurship activities, Entrepreneurship and Sustainability Issues 4(1): 17-24.

DOI: http://dx.doi.org/10.9770/jesi.2016.4.1(2)

JEL Classifications: D73, K14, O17

\section{Introduction}

Sustainable development of entrepreneurial activities requires respective favourable multi-faceted environment (Laužikas et al. 2015, Tvaronavičienè 2015; Civelek et al. 2016). In some cases, when business is performed in conditions of high taxation (Astrauskaite, Paškevičius 2016; Dobrovič et al. 2016, Kozubíková, Zoubková 2016), or atmosphere of skeptical treatment of social responsibility (Mostenska, Bilan 2015) phenomena of shadow economy (Caurkubule, Rubanovskis 2014; Belás et al. 2015) or corruption start thriving, what creats "criminal environment". 


\section{The International Journal \\ ENTREPRENEURSHIP AND SUSTAINABILITY ISSUES}

ISSN 2345-0282 (online) http://jssidoi.org/jesi/

2016 Volume 4 Number 1 (September)

There is no agreement regarding the understanding the category of "criminal environment". For instance, an outstanding Russian jurisprudent, an expert in the field of criminology and criminal psychology, Y. M. Antonyan writes: "One must consider criminal environment only as a group (or several groups) of people whose members commit crimes" (Antonyan 1975).

There is also another definition of criminal environment considering the contemporary context: it is a social, criminal phenomenon which is formed from a definite number of people who are engaged in criminal activity. Most of these people have been previously convicted and most of them are the bearers of the criminal subculture. The aim of these people is to commit intentional crimes and to escape liability (Operational and Search).

The most important psychological feature of the criminal environment is the subculture. Latin term "subculture" ( $s u b$ - under; under something) means a part of the main culture. Criminal subculture unites law breakers and functions as a controller of their behaviour. But its major danger lies in the fact that it distorts public conscience, transforms criminal experience, leads to moral decline, blocks the process of the socialization of the youth, forms a public opinion about expediency of breaking particular rules of law (for instance, tax evasion), creates a positive image of some categories of criminals and, on the contrary, criticizes the citizens who help law-enforcement officers to arrest the criminals. To put it differently, criminal subculture is the basic criminalisation mechanism of communities and above all of youth environment.

On frequent occasions general public do not reproach criminals who have committed a crime in the economy sphere. On the contrary, they support them. It especially concerns the employers who pay the so called "underthe-table" wages, businessmen who avoid paying taxes, smugglers who transport illegal tobacco goods and alcohol transborder the European Union. In our society for reasons undefined it is thought that to cheat one's country is as near as a heroic deed. A person who has cheated his country is believed not to harm the general public; that is why they do not reproach him or her. However, it is necessary to remember that income that is not reported to the country causes financial loss of the citizens by decreasing the budget of the social sphere.

Security serves as precondition of societal development hence various facets of public security are being widely discussed (Matvejevs 2013; Zahars, Stivrenieks 2015). At the same time it increased the dimension of understanding the security aspect, extending it on economic, political, crime rate, etc. areas (Teivāns-Treinovskis, Jefimovs 2012). The connection of crime to social, political, economic and cultural conditions of human existence is beyond doubt. The conclusion about crime social determination is generally confirmed. However, optimistic forecasts and hopes that it would decline and wither away during the process of industrial development justify themselves neither in developing countries, nor in developed ones, nor in capitalistic ones, nor in socialist ones. At the same time the registered crime level in different countries and world regions can differ by one order and more, but crime dynamics in some countries and during some years can be positive (Luneev 2005). There are numerous reasons for that including socioeconomic ones.

Professor Graeme Newman of School of Criminal Justice, State University of New York, USA, suggested an unusual idea of interconnections peculiarity between the economy development level and crime. Although he agrees that in the USA and other developed countries crime level is really very high, it, as he puts it, causes less concern of the general public than in poor countries. Newman suggested a truly pragmatic American explanation by comparing crime to a stone and the economy to a pond. If one throws a big stone in a small puddle, the water will spill all over the ground. If one dumps a pile of stones from several trailers in a huge lake, the lake can remain practically unaffected. The author gives corresponding calculations and evidence, but after that he concludes that when the economic development level rises, crime impact may decrease in spite of its growth in number (Newman 1990). 


\section{ENTREPRENEURSHIP AND SUSTAINABILITY ISSUES \\ The International Journal}

ISSN 2345-0282 (online) http://jssidoi.org/jesi/

2016 Volume 4 Number 1 (September)

\section{The shadow economy}

The shadow economy is present in the countries all over the world. For the especially privileged ones there are offshore financial institutions and other "peaceful havens". The basic differences of the shadow economy lie in its amount, methods of how it is carried out and in the socio-juridical control level over it. The shadow economy exerts a negative impact on state budget income and hinders competition in business environment.

The shadow economy essence can be defined from different perspectives. In economic analysis economicstatistical definition of the shadow economy is usually used as a basis: the shadow economy is all types of economic activity that are not represented in the official statistic.

It is possible to consider the definition of the shadow economy from another point of view: legally it can mean all the economic processes which come into conflict with legal rules - both with civil-legal ones and with criminallegal ones.

Thereby, a thorough theoretical thought is necessary to talk about the formation of a new concept that concerns cross-industry interaction of regulations of civil and criminal law in terms of improving legal adjustment directed to illegal business activity (Leskova, Didenko 2016).

The annual study of Stockholm School of Economics in Riga that focuses on the shadow economy in the Baltic States has shown that the amount of the shadow economy in Latvia in 2015 came down slightly compared with 2014 whereas in Lithuania and Estonia there was a slight increase in the amount of the shadow economy.

The amount of the shadow economy expressed as a percentage of a country gross domestic product (GDP) showed an increase of $21,3 \%$ in Latvia in 2015; in Lithuania it was $15 \%$, but in Estonia it was $14,9 \%$. During the year decrease of the shadow economy amount in Latvia comprised 2,2\% of GDP; however, the shadow economy in Latvia is nevertheless higher than in the two neighbouring Baltic states.

"Despite the fact that the basis of the shadow economy decrease in Latvia lies generally in the decrease of the unreported incomes of the businessmen and of the amount of "under-the-table" wages, these indices for our country are still evaluated as very high", admits the author of the present research, Prof. Asoc. Dr. Arnis Sauka of SSE Riga. The highest level of the shadow economy is in Riga and its outskirts; the second place is taken by Kurzeme region.

The biggest part of the shadow economy of Latvia is comprised of incomes concealed by businessmen, i.e. tax evasion (about $45 \%$ of all the shadow economy). The rate of income concealment by businessmen in Latvia is much higher than in the neighbouring Baltic States: in Latvia it is 19,9\% in comparison with 10,5\% in Lithuania and $7,5 \%$ in Estonia. It is also necessary to note that according to the research data (Ënu ekonomikas indekss, 2016) unregistered companies make up about 5-7\% of the number of all the companies in Latvia. In the research it is concluded that smaller and newer companies tend to be drawn into the shadow business activity proportionally more often than larger and older ones.

The second important part of the shadow economy of Latvia comprises the so called "under-the-table" wages. In year 2015 the level of the "under-the-table" wages in the Baltic States was roughly the same - within the range of $15,2 \%-17,9 \%$. It should be mentioned that in Latvia this tendency towards decrease of the "under-the-table" wages of the total amount of wages has been taking place since 2010 up to the present moment. Whereas in Estonia unofficial wages (wages paid "under-the-table") are the major part of the shadow economy and make up about $60 \%$ of its total amount. 


\section{ENTREPRENEURSHIP AND SUSTAINABILITY ISSUES \\ The International Journal}

ISSN 2345-0282 (online) http://jssidoi.org/jesi/

2016 Volume 4 Number 1 (September)

Traditionally, the largest part of the shadow economy in business activity in Latvia is accounted for by building sector - about $40 \%$ of amount of work in this sector is being conducted in the "grey zone". In Lithuania and Estonia, according to the conducted research, these indices are half lower.

The shadow economy is called like that generally because it is unaccounted, illegal, and concealed from the government, i.e. it lies beyond legal conditions. If one disengages oneself from the destructiveness feature of the shadow economy, it can soundly be treated as the direct result of socio-legal absence of control. This absence of control may be connected with the unsatisfactory legal notices (the presence of blanks, insufficiency, or distortion) or with their unsatisfactory execution by the officials of the economy structures and regulating agencies (neglect, abuse, corruption, and etc.). Thus, the problem of the shadow economy minimization lies generally in optimization of socio-legal control, which, on the one hand, would stimulate the transparency and justification of legally authorized business activity, and which, on the other hand, would not discourage the initiative of the people involved in this activity (Luneev 2005). As far as the "black" (criminal) economy is concerned - the economy in the sphere of the criminal activity (for instance, arms trafficking, drugs trafficking, human trafficking, and etc.) the socio-legal control in this sphere must be absolutely uncompromised.

The illegal shadow economy actions can represent civil, tax, administrative and criminal delinquencies. The latter are directly connected with the criminological aspect of the shadow economy, but the rest violations are connected both directly and indirectly as they create different criminogenic conditions, i.e. conditions in furtherance of committing mercenary economic crimes in spite of the fact that they are not criminal by their nature. Thus, practically all the shadow economy is criminogenic to some extent.

Similarly to any other type of crime, criminal business is connected with the whole system of the social relations including the socio-legal control, the importance of which was mentioned above. Obviously, the economy cannot develop effectively without the socio-legal control. It immediately turns into the criminal one with all the corresponding consequences. In chase of profit and excess profit, criminal business employs all the means possible.

Security of society is one of preconditions and driving factors of sustainable economic development (Ivančiks, Tumalavičius, Teivāns-Treinovskis 2015). Modern globalisation processes linked with the creation of polycentric relationships in the framework of the world community have made the problem of criminal law policy optimization topical in the sphere of ensuring inviolable rights and legal interests of a person. Intensifying migration processes and negative consequences of political and legal confrontation have inevitably led to the acceleration of crime growth rate both on the international and on the national level. As the result, a strategic direction to renew the national politics principles of the countries focuses on devising a balanced criminal and legal policy based on poising the principles of the national, subnational and international law that secure coherent functioning of the national law systems, their vitality and reproduction in the context of socio-interactive diversity (Avdeev 2016).

The conclusions are quite obvious. A complex critical analysis of present economic, criminological and legal fundamentals is necessary. Realistic minimisation of the criminal shadow economy is possible only on condition that the state and society do difficult two-unit tasks: secure freedom and safety, freedom and socio-legal control, efficient fight with the intensively growing criminal activity, and strictly observe the fundamental human rights.

It is important to draw the attention to one more aspect of the criminal environment that influences the economy generally and business activity particularly: it is corruption. The shadow economy undoubtedly causes corruption, but corruption in its turn forms the basis for the shadow economy flourishing. 


\section{ENTREPRENEURSHIP AND SUSTAINABILITY ISSUES}

ISSN 2345-0282 (online) http://jssidoi.org/jesi/

2016 Volume 4 Number 1 (September)

\section{Corruption}

Corruption is a many-sided phenomenon which despite diversity of political, legal and economic systems in different countries where it exists shares common trends of its development. Moreover, its history is as ancient as the civilization itself. Corruption significantly influences stability and security of many countries, undermines democratic and moral principles as well as hampers the economic and political development of the countries. That is why the world community treats corruption as the major social problem to solve which is the priority in crime fighting.

The modern stage of legal development is characterized by globalization of the international life determined both by negative and positive trends. Corruption has become one of the most negative and difficult social phenomena. Its extent can lower the efficiency of state institutions activity and significantly damage reputation of the state authorities as a whole as well as state prestige in the international arena. Corruption causes a number of economic, social and political consequences. The economical ones are, for instance, the shadow economy expansion, ineffective allocation of budget funds and violation of the market competition mechanisms (Mamytova 2016).

Ineffective allocation of budget funds, distributing state orders and credits in particular, leads to the drop of quality and amount of social services and goods which the state provides for its citizens and business.

The destructive impact of corruption on business activity is obvious. The violation of the market competition mechanisms leads to the situation when the winner is not the one who is able to meet the competition, but the one who has managed to gain the advantage due to the bribes. As the result, the appearance of effective private owners is hampered. This leads to the decline of the market efficiency as well as to discrediting the idea of the market competition in general. The investment climate worsens, and the problems to overcome the production decline and to renew fixed assets are not being solved.

Collapse in confidence of the market participants in the authorities generally takes place as the result of the loss of trust in the ability of the authorities to establish and follow fair game rules.

In year 2015 the survey Fraud and Corruption - the easy option for growth? of the organization EY (Ernst \& Young) (Fraud and corruption 2015) revealed that in the countries with the developed economy 35\% respondents agreed that corruption in their countries is widely spread.

Corruption in Latvia is a commonplace according to $55 \%$ polled within the framework of the study of the representatives of the large-scale enterprises in the country. In Lithuania and Estonia this figure is much lower: $45 \%$ and $21 \%$ respectively.

In France $29 \%$ polled agreed that bribes and corruption are commonplace, in Germany the figure was $26 \%$, in Sweden it was $10 \%$, and in Denmark the figure was $4 \%$. In Russia this figure was $60 \%$, in Slovenia it was $87 \%$, and in Croatia it was 92\%. 3800 large-scale company employees of 38 countries took part in the polls on the whole.

According to Corruption Perceptions Index of the international organisation leading the fight against corruption Transparency International (Transparency International 2016), the least corrupt countries in 2016 (according to the data of year 2015) were Denmark, Finland, and Sweden, but the most corrupt ones were Somalia, North Korea and Afghanistan. Meanwhile, the most corrupt country in Europe was again named Ukraine, which got 27 points and took the $130^{\text {th }}$ place.

The situation in Latvia compared with the previous year has not changed. Latvia got 55 points out of 100, where 100 means the total absence of corruption and 1 means total corruption. In the rating of 167 countries, however, 


\section{ENTREPRENEURSHIP AND SUSTAINABILITY ISSUES \\ The International Journal}

ISSN 2345-0282 (online) http://jssidoi.org/jesi/

2016 Volume 4 Number 1 (September)

Latvia has moved from the $43^{\text {rd }}$ place to the $40^{\text {th }}$ place due to the changes in other countries. The country shares this place with Cape Verde, Costa Rica and Seychelles.

Still, Latvia remains far behind Estonia, which got 77 points and which took the $23^{\text {rd }}$ place. Lithuania outdistanced Latvia as well by getting 61 points and took the $32^{\text {nd }}$ place.

Corruption in Latvia costs up to $\$ 5,67$ milliard dollars (5,08 milliard euros) annually, according to the research requested by the European Parliament in RAND Europe institute (The Cost of Non-Europe, 2016).

Taking in account three different indices of corruption perception the researchers came to the conclusion that because of the corruption Latvia annually loses from $13,16 \%$ to $19,24 \%$ of its gross domestic product (GDP), which is from 3,4 milliard to 5,08 milliard euros.

Such countries as Lithuania, Poland, Slovakia, Romania, Bulgaria, Croatia, Greece and Italy suffer similar losses because of corruption. On the whole the European Union losses because of corruption are estimated from 179 milliard to 990 milliard euros annually.

It is possible to determine four main ways of corruption impact on economic activity of entrepreneurs: firstly, corruption increases investment return aimed at the rent-seeking; secondly, corruption exerts a negative impact on small and medium-sized businesses; thirdly, corruption makes innovation activities less attractive for the entrepreneurs; finally, high level of corruption reduces the amount of direct foreign investments.

The explanation of how corruption stimulates rent-seeking behaviour of economic agents results directly from the well-known theoretical model of Andwig and Moene: the increase in the number of corrupt authorities decreases the probability of exposure of the corrupt bargain as well as transaction expenses of searching for the counteragents for potential bribers. This contributes to the growth of the investments attractiveness in the rent-seeking for the latter (Andvig, Moene 1990). Naturally, the resources spent on the rent-seeking cannot be spent again in any other effective society-oriented way. Thus, by stimulating rent-seeking behaviour, corruption exerts a negative impact on the investment activity of the entrepreneurs.

\section{Conclusions}

It is worth pointing out that despite different researches conducted in this sphere, one of the drawbacks of the corruption conditions analysis is the absence of its whole representation in the official criminal statistic. Similarly, it is not studied broadly enough in the analytical enforcement documents. The abeyance of corrupt economic crimes remains very high.

It is possible to conclude that corruption and the shadow economy are intimately bound up and cause one another. The shadow sector is a perfect place for corruption flourishing as it lies beyond the legal protection. Nowadays corruption exerts an essential influence on all the spheres of a human life as well as on the economy branches including business activity; to fight it effectively the whole society must participate in it. As far as business activity is concerned, the impact of corruption is multi-faceted: ranging from the decrease of business profit because of "under-the-table" payments to the direct refusal of doing business because of the lack of prospects.

Thus, the negative impact of crime on the business activity is obvious. Moreover, this impact may be multifaceted depending on different types of criminal activity of the groups of people in the particular region. The logical way out from this situation is the elimination of obstacles to legal business activity and imposing such

conditions that would make the operation of illegal business activity organizations impossible. 


\section{ENTREPRENEURSHIP AND SUST \\ The International Journal}

ISSN 2345-0282 (online) http://jssidoi.org/jesi/ 2016 Volume 4 Number 1 (September)

\section{References}

Andvig, J. C.; Moene, K. O. 1990. 'How Corruption May Corrupt', 13(1) Journal of Economic Behavior and Organization, 63-76

Antonyan, Y. M. 1975. Social Environment and the Criminal Personality Formation (Negative Impact on a Personality in the Microenvironment). Moscow, p. 20.

Astrauskaite, I.; Paškevičius, A. 2016. Assessing the optimal taxation of the capital income: a case of corporate bond market, Journal of Security and Sustainability Issues 5(4): 519-532. DOI:http://dx.doi.org/10.9770/jssi.2016.5.4(7)

Avdeev, V.A.; Avdeeva, O.A.; Gribunov, O.P.; Sergevnin, V.A. 2016. Punishment in the System of Criminal and Legal Countermeasures against Crime: Legal Systems Interaction in the Context of International Life Globalization. Criminology Journal of Baikal National University of Economics and Law. 2016. v. 10, Nr. 2. p. 301-312.

Belás, J., Bartoš, P., Ključnikov, A., Doležal, J. 2015. Risk perception differences between micro-, small and medium enterprises, Journal of International Studies 8 (3): 20-30.

Caurkubule, Ž.; Rubanovskis, A. 2014. Shadow economy as an obstacle to sustainable Economic development, Journal of Security and Sustainability Issues 4(2):175-186. DOI: http://dx.doi.org/10.9770/jssi.2014.4.2(6)

Civelek, M., Ključnikov, A., Dobrovič, J., Hudakova, M. 2016. A model of measurement of the quality of business environment in SME segment, Journal of International Studies 9(2): 90-102.

Dobrovič, J.; Korauš, A.; Dančišinová, L. 2016. Sustainable economic development of Slovakia: factors determining optimal tax collection, Journal of Security and Sustainability Issues 5(4): 533-544. DOI: http://dx.doi.org/10.9770/jssi.2016.5.4(8)

Ēnu ekonomikas indekss Baltijas valstīs 2009-2015. 2016. Stockholm school of Economics in Riga. Available on the Internet: <http://www.sseriga.edu/en/news-and-events/upcoming-events/enuekonomikaskonference2016.html>.

Fraud and corruption - the easy option for growth? Europe, Middle East, India and Africa Fraud Survey 2015. Available on the Internet: 〈http://www.ey.com/Publication/vwLUAssets/ey-emeia-fraud-survey/\$FILE/ey-emeia-fraud-survey.pdf $>$

Ivančiks, J.; Tumalavičius, V.; Teivāns-Treinovskis, J. 2015. Security of society: narcotics and drug addiction in Latvia and Lithuania, Journal of Security and Sustainability Issues 4(4): 353-368. DOI: 〈http://dx.doi.org/10.9770/jssi.2015.4.4(4)〉.

Kozubíková, L., Zoubková, A. 2016. Entrepreneur's attitude towards innovativeness and competitive aggressiveness: The case study of Czech micro-enterprises, Journal of International Studies 9 (1): 192-204.

Laužikas, M.; Tindale, H.; Bilota, A.; Bielousovaitè, D. 2015. Contributions of sustainable start-up ecosystem to dynamics of start-up companies: the case of Lithuania, Entrepreneurship and Sustainability Issues 3(1): 8-24. http://dx.doi.org/10.9770/jesi.2015.3.1(1)

Leskova, Z. G.; Didenko, A. A. 2016. Illegal Business: Changes of Corpus Delicti Features from the Standpoint of the Civil Law Reformation of the Russian Federation. Criminology Journal of Baikal National University of Economics and Law. v. 10, Nr 1. p. $96-104$.

Luneev, V.V. 2005. Crime and the Shadow Economy. Economic Science of Modern Russia Nr.1 (28) 2005.

Mamytova, N.V. 2016. Problems of Fighting Corruption Crimes in the Russian Federation. Criminology Journal of Baikal National University of Economics and Law v. 10, Nr.2. p.261-269.

Matvejevs, A. 2013. Legal regimes in police activity at Latvian security policy, Journal of Security and Sustainability Issues 3(1): 23-30. Mostenska, T.; Bilan, Y. 2015. Sustainable development through enhanced social responsibility, Journal of Security and Sustainability Issues4(3):536-551. DOI: http://dx.doi.org/10.9770/jssi.2015.4.3(4)S

Newman, G. 1990. Crime and the Human Condition. Essays Crime and Development. UN1CRI, Rome, p. 80-82. Operational and Search Characteristic of Modern Criminal Environment. Available on the Internet: <http://bibliofond.ru/view.aspx?id=582779>>.

Teivāns-Treinovskis, J.; Jefimovs, N. 2012. State national security: aspect of recorded crime, Journal of Security and Sustainability Issues 2(2): 41-48. 


\section{ENTREPRENEURSHIP AND SUSTAINABILITY ISSUES \\ The International Journal}

ISSN 2345-0282 (online) http://jssidoi.org/jesi/ 2016 Volume 4 Number 1 (September)

The Cost of Non-Europe in the area of Organised Crime and Corruption. 2016. Annex II - Corruption European Parliamentary Research Service. European Added Value Unit PE 579.319, March 2016.

Transparency International. Table Of Results: Corruption Perceptions Index 2015. 2016. Available on the Internet: <http://www.transparency.org/cpi2015>.

Tvaronavičienè, M. 2016. Start-ups across the EU: if particular tendencies could be trace, Entrepreneurship and Sustainability Issues 3(3): 290-298. http://dx.doi.org/10.9770/jesi.2016.3.3(6)

Jānis TEIVĀNS-TREINOVSKIS - PhD, Professor, is a Dean of Faculty of Social Sciences of Daugavpils University. Research interests: criminal law, penal law, criminology.

Jeḷena AMOSOVA - is a PhD student at Daugavpils University. Research interests: criminal law classification, application of criminal law.

Copyright (C) 2016 by author(s) and VsI Entrepreneurship and Sustainability Center

This work is licensed under the Creative Commons Attribution International License (CC BY).

http://creativecommons.org/licenses/by/4.0/

(c) (i) Open Access 